\title{
Archeologický výzkum mohyly a domu kůlové konstrukce ve Velkém Přítočně, okr. Kladno
}

\author{
The archaeological research of a burial mound and a stilt structure \\ in Velké Př́točno, Kladno district
}

\author{
Petr Menšík / Milan Procházka
}

\begin{abstract}
Abstrakt
V roce 2011 byl proveden záchranný archeologický výzkum na katastru obce Velké Přítočno, okr. Kladno. Na skryté ploše o rozloze 1,5 ha byly identifikovány dvě koncentrace nálezů. První koncentrace představovala kůlové jamky, které na základě vzájemných prostorových vztahů a analogií interpretujeme jako zbytek kůlového domu, přičemž lze uvažovat o jeho dataci do doby bronzové. Druhou koncentrací archeologických situací byl pozůstatek kruhového žlabu o průměru 10-12 m vyplněného velkými kameny, snad pozůstatkem kamenného věnce. Ty nebyly na pưvodním místě usazení zřejmě vlivem předchozí orby. Plocha uvnitř věnce byla vyplněna zeminou tmavšího charakteru a dvěma koncentracemi kamenů. Vzhledem k nízké mocnosti ornice a aktivnímu zemědělskému využití v místě skrývky bylo narušení objektu patrno i v charakteru nálezů. Podle typologie objektu a získaného keramického materiálu můžeme pravděpodobně hovořit o pozůstatku mohyly zařaditelné snad do doby bronzové. Vzájemnou souvislost kůlového domu a mohyly nelze prokázat. Spolu s jinými př́klady z poslední doby tak nález přispívá k problematice „zmizelých” rozoraných mohylníků ve středních Čechách.
\end{abstract}

\section{Klíčová slova}

doba bronzová, mohyla, kamenná konstrukce, pohřební ritus

\begin{abstract}
In 2011, a rescue archaeological excavation was made in the Velké Př́točno cadastre, Kladno district. In the stripping area of $1.5 \mathrm{ha}$, two main concentrations of findings were identified with the first one being formed by pile holes interpreted as the rest of a stilt house. The interpretation was based on spatial correlations and analogies resulting into a possibility to speculate about its affiliation to the Bronze Age. The second concentration of archaeological situations was a remnant of a circular through, having 10 12 metres in diameter, filled with large stones which were possibly formed to a stone ring. The surface inside the ring contained darker soil and two stone accumulations. According to the typology of the feature and basic characteristic of the gained archaeological material, it is possible to presumably speak about the remains of a burial mound assignable to the Bronze Age. The association of the stilt house with the burial mound is impossible to prove. Among other recent examples, the finding significantly contributes to the issue of a "disappeared" plowed up burial site in Central Bohemia.
\end{abstract}

\section{Keywords}

Bronze Age, burial mound, stone construction, burial rite 


\section{1. Úvod}

Nedaleko obce Velká Dobrá na Kladensku se v roce 2011, při záchranném archeologickém výzkumu, podařilo prozkoumat pravidelnou kůlovou konstrukci ukazující na přítomnost nadzemní stavby kůlové konstrukce. Druhým zjištěním byl zbytek kamenného věnce, který představoval spodní partii téměř zničené mohyly. Cílem příspěvku je prezentace těchto nálezů, které se ve středních Čechách dochovaly pouze v omezeném počtu a nejsou doposud většinou publikovány.

\section{Popis výzkumu a archeologických objektů ${ }^{1}$}

V průběhu července a srpna roku 2011 byl $\mathrm{v}$ rámci skrývky pro výstavbu řadových rodinných domů proveden plošný odkryv na ploše přibližně 1,5 ha v intravilánu obce Velká Dobrá, která se nachází v bezprostředním jižním sousedství města Kladno (Obr. 1). Místo je možné lokalizovat nedaleko polní trati „V dolcích, Na Radkovech“, v nadmořské výšce 386-390 metrů, v pramenné pánvi přibližně 100 metrů od dnes meliorovaného toku Dolanského potoka a lze jej vymezit koordináty GIS-JTSK -763000: - 1036940 a - 762880 : - 1036820. Výzkum byl proveden Českou archeologickou společností, o.p.s. pod vedením M. Procházky. Na ploše se podařilo odkrýt celkem 35 objektů, které lze rozdělit do dvou základních komponent. První představuje kruhový příkop vyplněný pravděpodobně zbytky kamenného věnce, který původně představoval konstrukci mohylového náspu. Druhou je poté koncentrace kůlových jamek tvořící pravidelný půdorys původně nadzemního kůlového domu ${ }^{2}$. $\mathrm{V}$ př́ípadě obou komponent se přikláníme $\mathrm{k}$ možné dataci do doby bronzové.
Objekt 10: oválná jáma sídlištního charakteru o rozměrech $210 \times 165 \times 43 \mathrm{~cm}$, s mírně šikmými konkávními stěnami a pravidelným konkávním dnem, vyplněná černou, ulehlou, jílovitou hlínou. Objekt se nacházel v jižní části zkoumané plochy mimo kruhový př́kop a kumulaci kůlových jamek. Bez nálezů. Datace: pravěk?

Objekt 11: kruhový př́kop vnějšího průměru 10 $\times 12$ metrů (obr. 3, 7), dochovaná širŕka příkopu se pohybovala v rozmezí 90-230 cm (obr. 4-6), zejména v západní a jižní části žlabu se nalézala koncentrace kamenů z ruly a slepenců místního původu o průměru $20-80 \mathrm{~cm}$ tvořící původně pravděpodobně konstrukci kamenného věnce. Kameny v mnoha případech nebyly na původním místě usazení a byly mírně posunuty, zřejmě vlivem orby. Výplň žlabu byla tvořena šedočernou, ulehlou, jílovitou hlínou, ojediněle s lokální kumulací drobných zlomků zvětralé opuky (vrstva 1). V horních partiích žlabu byla vrstva 1 místy kontaminována peckami, případně vrstvičkami, zahliněného žlutého jílu, což bylo způsobeno zanášením žlabu, př́ípadně díky porušení orbou (vrstva 2 a 3). Na základě podoby výplně žlabu je možné, že k jeho zaplnění došlo jednorázově, př́ípadně v krátkém časovém intervalu. Kruhový příkop obklopuje vnitřní prostor, jehož střed byl vyplněn nepravidelnou zahloubeninou, která byla díky orbě a skrývce zachována pouze $\mathrm{v}$ torzu. $\mathrm{V}$ teoretické rovině se mohlo jednat o zbytek pohřební komory, hrob však nebyl identifikován. Její průměr byl $6 \times 4$ metry, měla nepravidelné dno s max. hloubkou $40 \mathrm{~cm}$. Jižní část byla vyplněna kamenným závalem stejného charakteru jako v př́ípadě žlabu, kameny však nepřesahovaly průměru $50 \mathrm{~cm}$. Zahloubenina byla tvořena šedočernou, ulehlou, jílovitou hlínou, stejně jako v případě žlabu. Jak v př́ípadě žlabu, tak vnitřního prostoru, nebyly často kameny umístěny v primární poloze, ale došlo k jejich přemístění orbou (obr. 3-6). Nálezy: ${ }^{3} 1 \times$ 


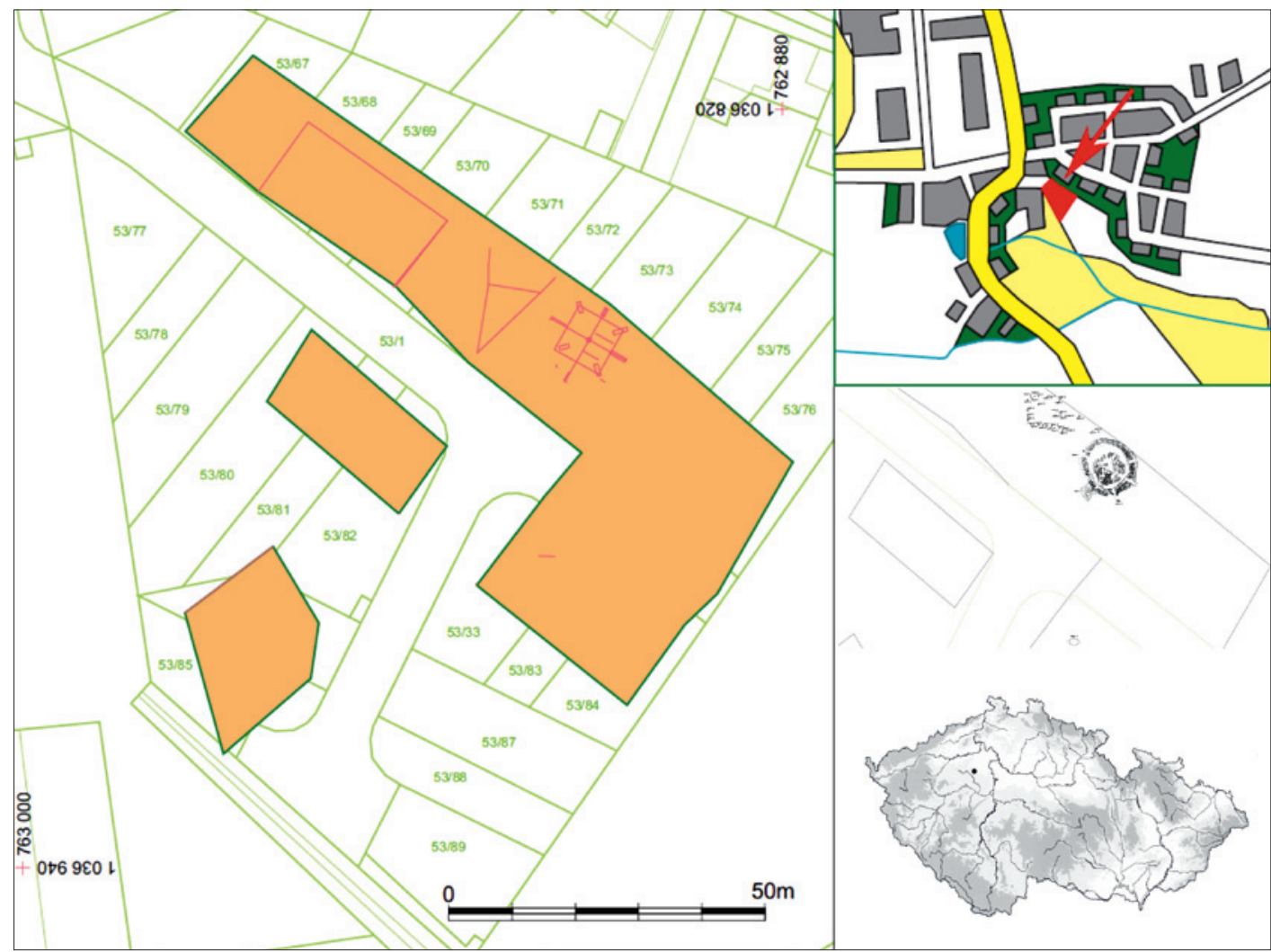

Obr. 1. Velké Př́točno, okr. Kladno. Lokalizace archeologického výzkumu.

Abb. 1. Velké Př́točno, Bezirk Kladno. Areal der archäologischen Untersuchungen.

zlomek bronzového předmětu (pravděpodobně šipka, bezprostředně po vyjmutí došlo $\mathrm{k}$ jejímu zničení vzhledem ke korozi); 1× ši (drobný úštěp z kř. typu Tušimice, délka 11, š. 8 , tl. 2 mm; $1 \times$ drobný zlomek z výdutě nádoby s otřelou lištou oranžové barvy, středněhrubá ker. třída, roz. 26 $\times 19 \times 4 \mathrm{~mm} ; 1 \times$ drobný zlomek vně vyhnutého okraje hnědé barvy, středněhrubá ker. třída, roz. $23 \times 19 \times 5 \mathrm{~mm}$; 40× drobné zlomky $\mathrm{z}$ výdutě tmavě hnědé - oranžové barvy, středně hrubé-hrubé ker. třídy (dr. kaménky do $7 \mathrm{~mm}$ ) do velikosti cca $30 \mathrm{~mm}$; 1× šedý střep z výdutě ze středněhrubým ostřivem s náznakem vlnicestřední doba hradištní (intruze v prostoru žlabu v hl. 10 cm); 1× světlehnědý novověký okraj keramické nádoby a světlehnědý zlomek kachle (druhotná poloha ve vrstvě 3). Datace: pravěk (doba bronzová?).

Objekt 12: mírně oválná jáma sídlištního charakteru o rozměrech $55 \times 60 \times 38 \mathrm{~cm}($ obr. 3,6$)$, $\mathrm{s}$ mírně šikmými konkávními stěnami a nepravidelným konkávním dnem, vyplněná černou, ulehlou, jílovitou hlínou. Objekt může souviset s konstrukcí žlabu, od kterého se nacházel ve vzdálenosti do 1 metru. Nálezy: 3× ker. zlomky z výdutě nádob šedooranžové barvy, hrubé až středněhrubé ker. hmoty. Datace: pravěk.

Objekt 13: mírně nepravidelná jáma sídlištního charakteru o rozměrech $180 \times 210 \times 50$ $\mathrm{cm}$, s mírně šikmými konkávními stěnami 


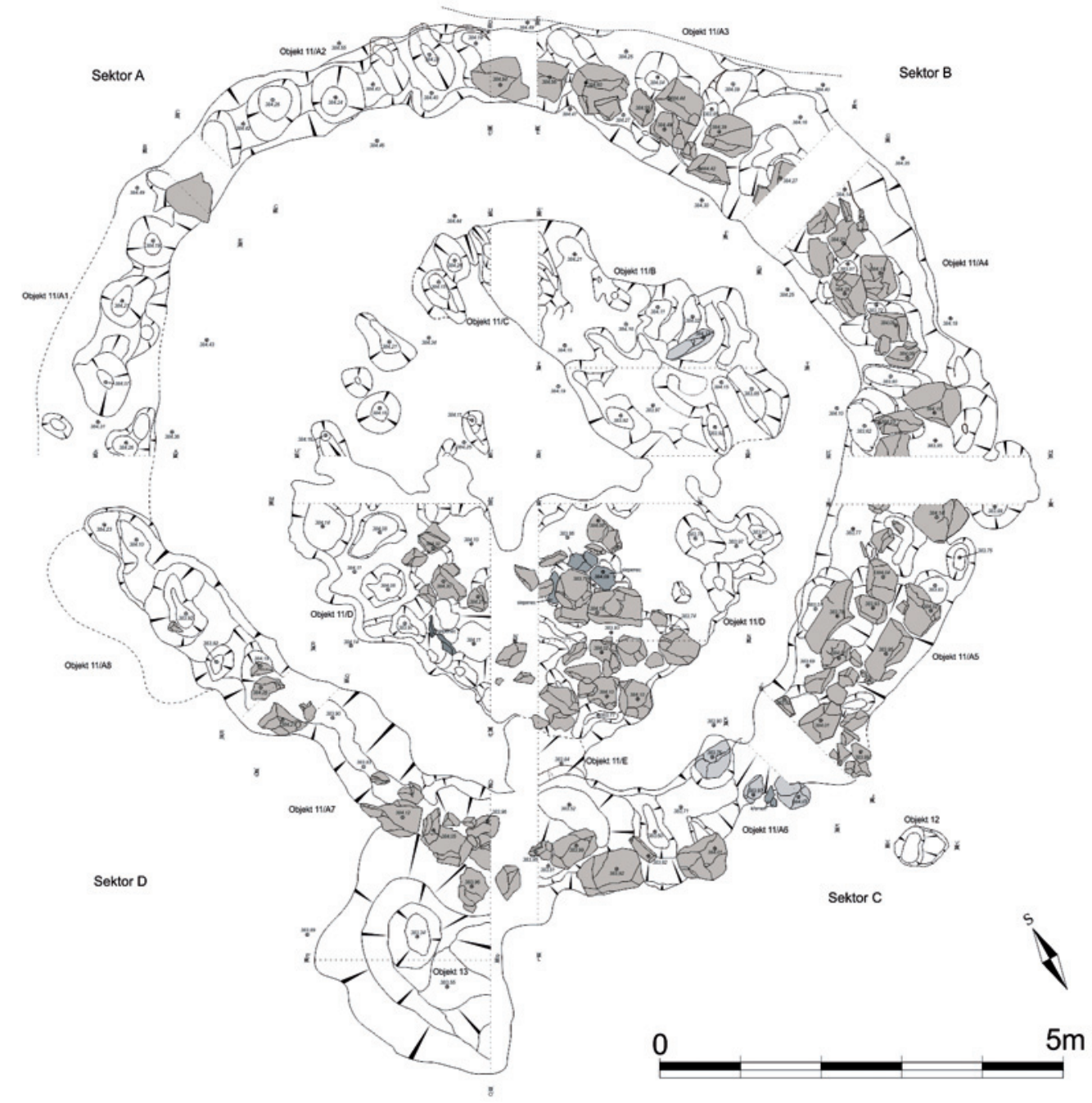

Obr. 2. Velké Přítočno, okr. Kladno. Terénní dokumentace objektu č. 11-13. Půdorys.

Abb. 2. Velké Př́točno, Bezirk Kladno. Geländedokumentation des Objekts Nr. 11-13. Grundriss. 


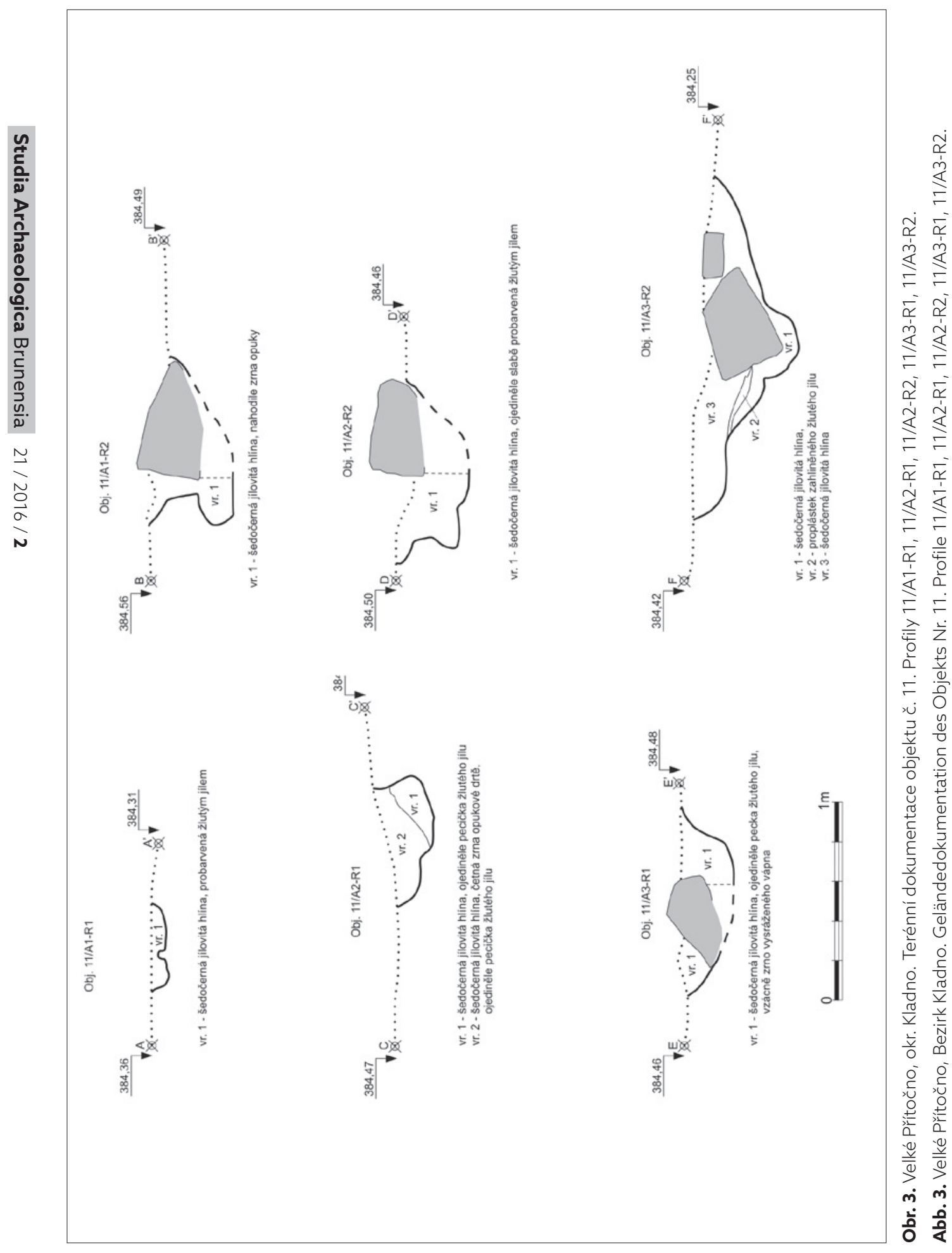




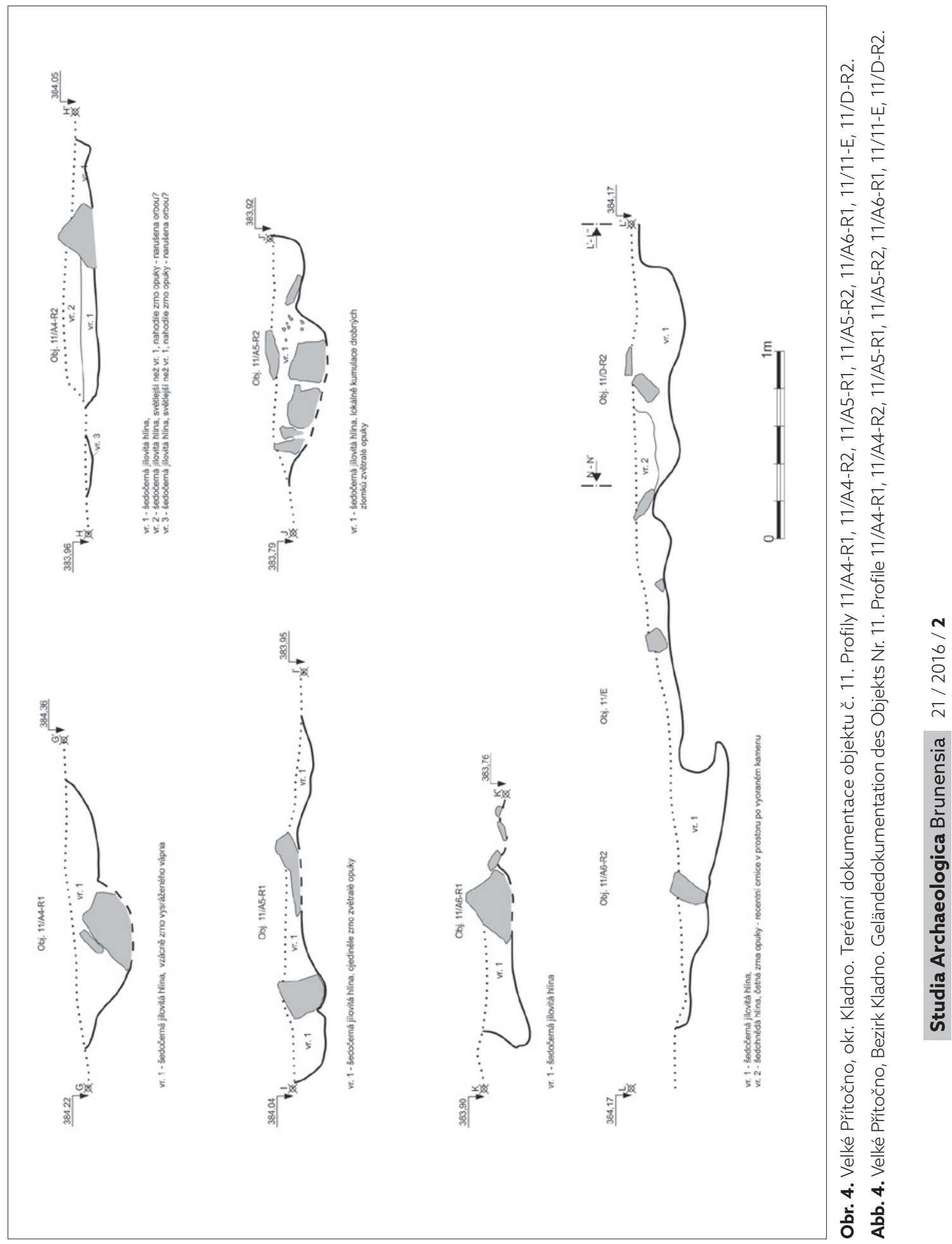




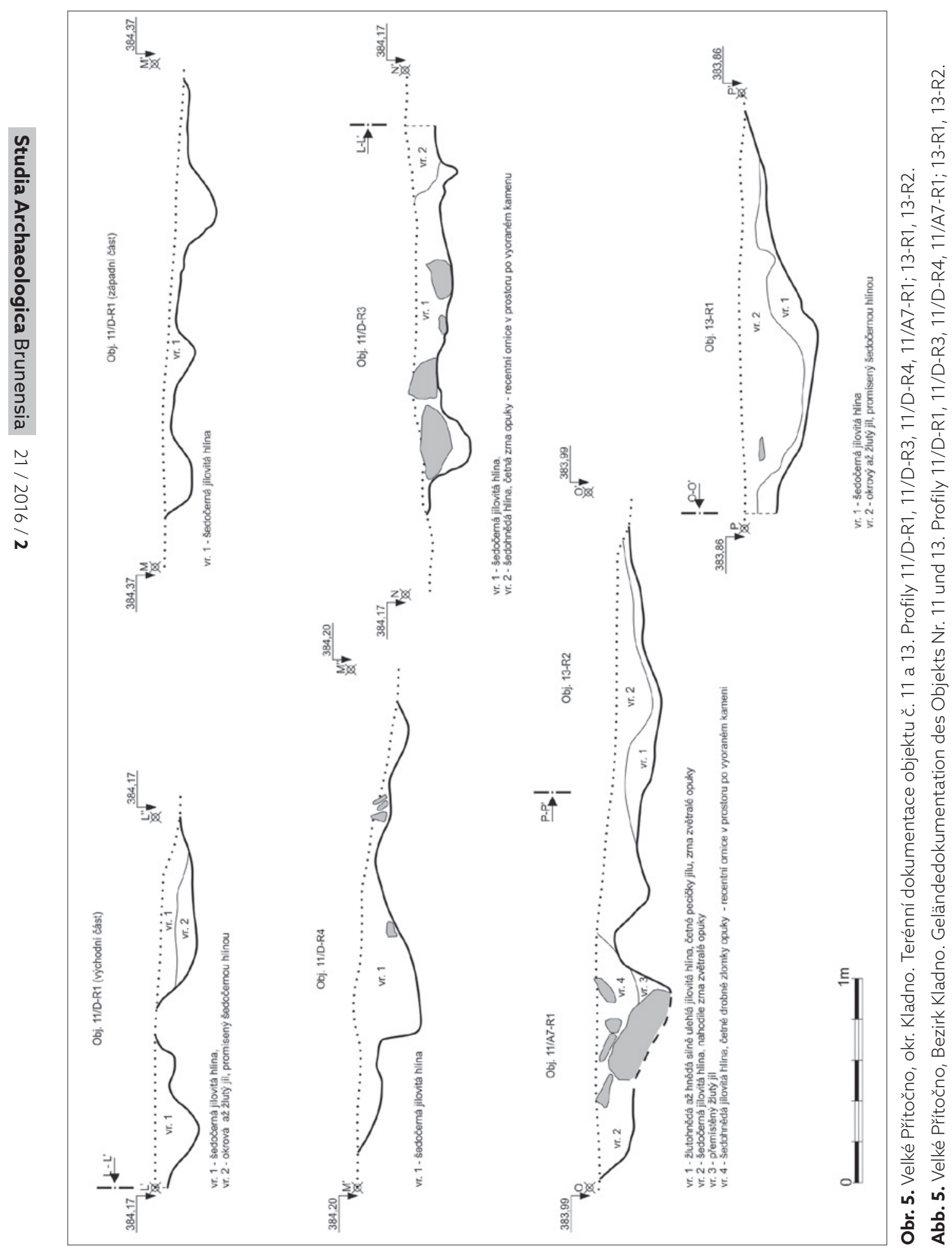




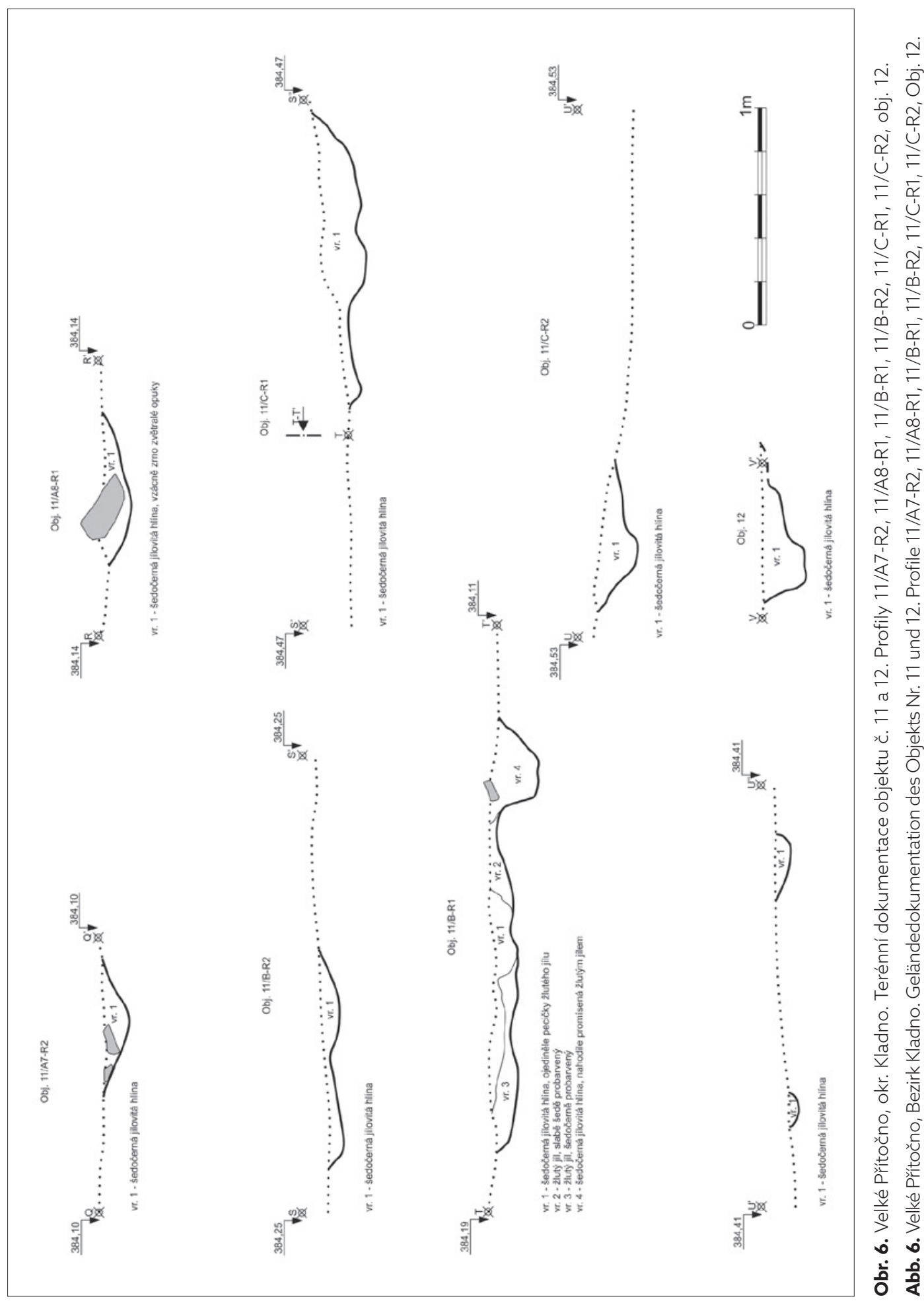


a nepravidelným konkávním dnem, vyplněná černou, ulehlou, jílovitou hlínou. Objekt může souviset s konstrukcí žlabu, na který bezprostředně nasedá z jižní strany (obr. 3, 5). Bez nálezů. Datace: pravěk?

Objekt 14-46: celkem 33 kůlových jamek tvořících západní část kůlové konstrukce domu dochovaného ve velikosti $4 \times 10$ metrů a orientací východ-západ (obr. 8). Původní velikost stavení nelze určit, východní část byla zničena orbou a část půdorysu zasahoval mimo prostor skrývky. Kůlové jáma č. 38 - č. 44 tvořily pravděpodobně vnitřní konstrukci. Z kůlových jam jsou zachovány pouze spodní partie, půdorys je víceméně kruhový, v některých případech mírně nepravidelný, s kolmými nebo mírně šikmými stěnami a pravidelným, rovným nebo mírně konkávním dnem. Kůlové jámy byly vyplněny vrs. 1 (hnědá jílovitá hlína, středně ulehlá), vrs. 2 (světle hnědá jílovitá hlína, stř̌edně ulehlá) nebo vrs. 3 (tmavě ulehlá jílovitá hlína, středně ulehlá). Rozměry: O. 14: rozm. $25 \times 33 \times 5 \mathrm{~cm}$, výplň vrs. 2; O. 15: rozm. $28 \times 25 \times 10 \mathrm{~cm}$, výplň vrs. 2; O. 16: rozm. $25 \times 23 \times 5$ cm, výplň vrs. 2 ; O. 17: rozm. $28 \times 23 \times 4$ cm, výplň vrs. 2; O. 18: rozm. $22 \times 23 \times 8 \mathrm{~cm}$, výplň vrs. 2; O. 19: rozm. $25 \times 25 \times 8$ cm, výplň vrs. 2 ; O. 20: rozm. $22 \times 20$ $\times 6 \mathrm{~cm}$, výplň vrs. 2; O. 21: rozm. $33 \times 30 \times 8 \mathrm{~cm}$, výplň vrs. 2; O. 22: rozm. $34 \times 30 \times 10 \mathrm{~cm}$, výplň vrs. 2; O. 23: rozm. $40 \times 30 \times 19$ cm, výplň vrs. 1; O. 24: rozm. $23 \times 22 \times 5$ cm, výplň vrs. 2; O. 25: rozm. $29 \times 29 \times 12$ cm, výplň vrs. 2; O. 26: rozm. $35 \times 32 \times 10 \mathrm{~cm}$, výplň vrs. 1; O. 27: rozm. $28 \times$ $26 \times 22$ cm, výplň vrs. 1; O. 28: rozm. $38 \times 34$ $\times 18$ cm, výplň vrs. 1; O. 29: rozm. $32 \times 28 \times 14$ cm, výplň vrs. 1; O. 30: rozm. $22 \times 23 \times 15 \mathrm{~cm}$, výplň vrs. 1; O. 31: rozm. $24 \times 23 \times 15 \mathrm{~cm}$, výplň vrs. 1; O. 32: rozm. $22 \times 28 \times 15$ cm, výplň vrs. 1 ; O. 33: rozm. $25 \times 28 \times 14$ cm, výplň vrs. 1; O. 34: rozm. $28 \times 28 \times 8 \mathrm{~cm}$, výplň vrs. 2 ; O. 35 : rozm. 35: $25 \times 23 \times 7 \mathrm{~cm}$, výplň vrs. 2; O. 36: rozm. 28 $\times 25 \times 11 \mathrm{~cm}$, výplň vrs. 1; O. 37: rozm. $23 \times 24 \times$
7 cm, výplň vrs. 1; O. 38: rozm. $14 \times 12 \times 20 \mathrm{~cm}$, výplň vrs. 3; O. 39: rozm. $13 \times 12 \times 5$ cm, výplň vrs. 1; O. 40: rozm. $32 \times 33 \times 12$ cm, výplň vrs. 1; O. 41: rozm. $26 \times 24 \times 22$ cm, výplň vrs. 3; O. 42: rozm. $13 \times 12 \times 15 \mathrm{~cm}$, výplň vrs. 3; O. 43: rozm. $30 \times 30 \times 14 \mathrm{~cm}$, výplň vrs. 3; O. 44: rozm. $25 \times 31 \times 13 \mathrm{~cm}$, výplň vrs. 3; O. 45: rozm. cca $22 \times 20 \times 3 \mathrm{~cm}$, výplň vrs. 3 ; O. 46: rozm. $38 \times$ $40 \times 20 \mathrm{~cm}$, výplň vrs. 3 (obr. 9-12). Bez nálezů. Datace: pravěk (doba bronzová?).

\section{Diskuse}

Přes to, že osídlení v době bronzové v okolí Velkého Přítočna není na základě současných poznatků příliš intenzivní, lze v okolí nalézt několik nálezů s doklady sídlení i pohřbívání. Nejbližší mohylové pohřebiště od námi sledovaného lokality se nachází 4 km západně, asi 1000 metrů SZ od Velké Dobré. Celkem 64 mohyl poskytlo nálezy ze střední a mladší doby bronzové a doby halštatské (Michálek 1999). V blízkosti pohřebiště je také uváděno sídliště mohylové kultury střední a mladší doby bronzové (Plesl 1965, 490). Stejně jako v případě Velkého Přítočna obsahovaly mohyly kamenný věnec se středovým kamenným jádrem i bez něj i středo-mladobronzové mohyly ve Velké Dobré (např. Hrala 1973, 121-124; Michálek 1999, obr. 17, 22) a představují tak bezprostřední analogie k analyzovanému objektu. Kamenný věnec se však objevuje i u mohyl ze starší doby bronzové, např. v př́ípadě únětické mohyly z Brandýsa nad Labem (Danielisová et al. 2013). Další mohylníky ze střední až mladší doby bronzové se nachází na katastru Blevic 13 km severovýchodním směrem, taktéž s kamenným věncem a jádrem (Sklenář 1992, 22-24; týž 2000), středobronzové mohylníky je možné lokalizovat také na katastrech obcí Lány (Beneš 1959, 40), Lhota (Moucha 1987, 249), Netovice (Schmidt 1893-1985; Beneš 1959, 42; Hájek HLAS 5086/1958), 


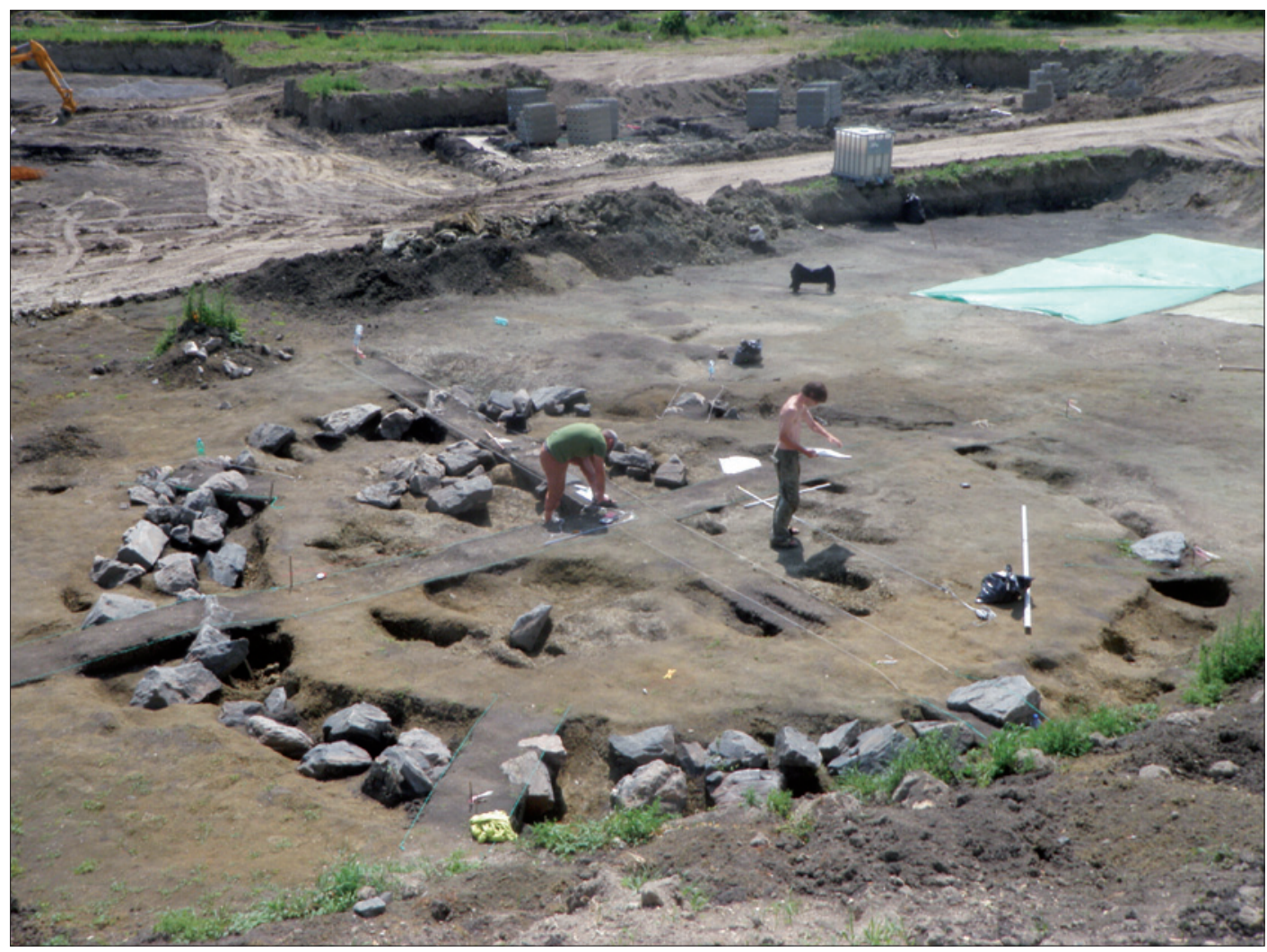

Obr. 7. Velké Prítočno, okr. Kladno. Foto obj. 11 při archeologickém výzkum. Foto M. Procházka.

Abb. 7. Velké Prítočno, Bezirk Kladno. Fotografie des Objekts 11 während der archäologischen Untersuchungen. Foto M. Procházka.

Stehelčeves (Knor HLAS 3621/1960) nebo Zvoleněves (Sklenář 1992, 285), z mladší doby halštatské u Stehelčevsi (Moucha 1985, 171-172; týž HLAS 3603/1988). Nedatované mohyly, snad pravěkého stáŕí, byly v minulosti zjištěny např. na katastrech obcí Doksy (Sklenář 1992, 49), Dřetovice (Sklenář 1992, 54), Hřebeč (Knor ZAA/641/1927), Kladno/Dubí (Sklenář 1992, 94), Koleč (Knor HLAS 2723/1962), Kováry (Knor HLAS 740/1934), Libovice (Knor HLAS 2676/1940), Svárov (Böhm HLAS 2805/1931; Wolf HLAS 4860/1947) nebo Vrapice (Sklenář 1992, 273). Ze střední doby bronzové jsou nálezy sídlištního charakteru známé pouze ojediněle, zmínit lze např. $13 \mathrm{~km}$ západně vzdálené Tuchlovice (Jančo 2003). Z katastru Velkého Pří- točna však pocházejí sídlištní nálezy knovízské kultury z polohy Za školou/Za sýpkou (Böhm HLAS 74/1932; Knor HLAS 608/1974; Knor HLAS 609/1974; Knor ZAA 1738/1978; Knor HLAS 7652/1962; Knor HLAS 3515/1979) a ze severního okraje obce (Moucha 1992, 162). Doklady rovinných sídlišst jsou poté známé i z okolních katastrů, např. Kyšic (Boháčová 1992, 77) nebo Hostouně (např. Dreslerová 2000, 52-53; Procházka 2012).

Prozkoumaný kruhový zahloubený objekt 11 (obr. 3-8) se vyznačuje určitou podobností s kruhovými žlaby, které bývají interpretovány jako pozůstatky obvodových žlabů po mohylách, jejichž nadzemní konstrukce se nedochovala (k problematice např. Turek-Sofaer 2004; 


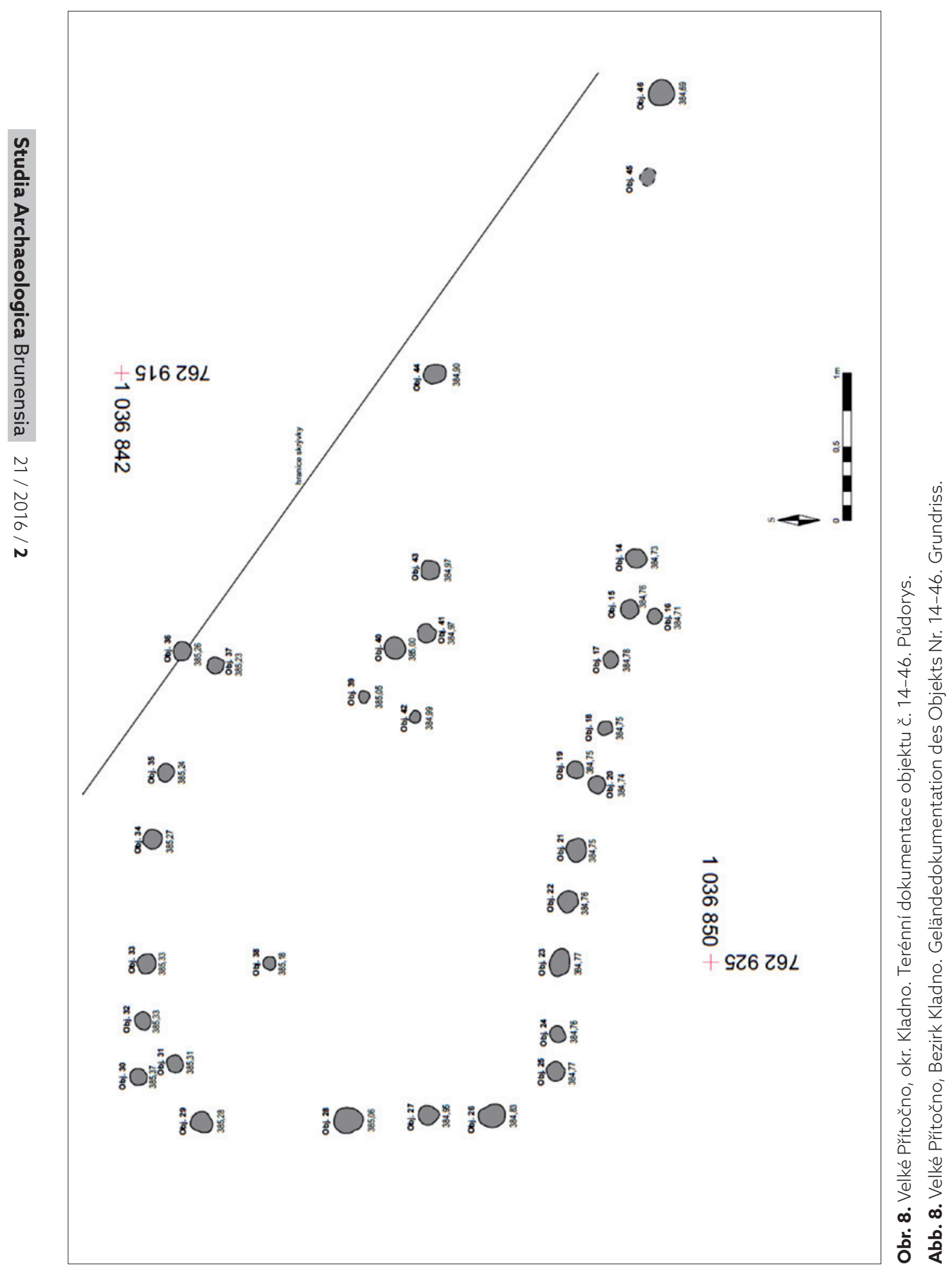


Kostka 2008; Trefný-Dobeš 2008; týž 2010; Švejcar-Baloun-Trefný 2012; k morfologii Gojda 1997, 37-40), přičemž je uvažováno i o interpretaci v podobě rovinných pohřebních kruhových areálů, v případě nedoloženého pohřbu pouze kruhových areálů s ne zcela jasnou funkcí, což platí zejména pro objekty řazené do skupiny malých kruhových ohrazení (srov. Trefný 2013). Obecně lze pozorovat značnou variabilitu jak po formální, tak chronologické stránce. Rozdíl oproti těmto objektům lze ve Velkém Přítočně vidět $\mathrm{v}$ přítomnosti kamenného závalu žlabu a také vnitřní části objektu se zbytky kamenné konstrukce, což není pro tyto objekty typické. Nebyl také zjištěn pohřeb v centrální hrobové komoře vymezené žlabem, případně př́ímo do žlabu (nález z Nymburku: Švejcar-Baloun-Trefný 2012). Chybí také časté přerušení žlabu směrem východním, popřípadě jiho/severovýchodním. Zbytek dokumentované kamenné konstrukce $\mathrm{v}$ podobě kruhového kamenného věnce a jádra však odpovídá konstrukcím, které byly zjištěny při odkryvech blízkých mohyl ve Velké Dobré (Píč 1992, 481-499; týž 1900, 160-161; Michálek 1999).

Mohyly beze stop vlastního pohřbu však nejsou jevem nijak výjimečným, tento fenomén se objevuje v různých pravěkých epochách (srov. Beneš-Michálek-Zavřel 1999, I, 105; Michálek-Zavřel 2010; Chvojka-Michálek-Zavřel 2011, 49), nacházely se pravděpodobně také na mohylníku ve Velké Dobré, kde celkem 17 prozkoumaných mohyl ze střední-mladší doby bronzové neobsahovalo žádné pohřby nebo archeologické nálezy (Píč 1992, 481-499; týž 1900, 160-161; Michálek 1999). V případě kruhového objektu 11 z Velkého Přítočna lze uvažovat o kenotafu, vzhledem k porušení objektu orbou a následnou skrývkou ovšem nelze vyloučit ani dřívější zničení pohřbu.

Další prostorovou strukturu v rámci zkoumané plochy tvoří kumulace kůlových jam (o. 14-46; obr. 9), přičemž se podařilo prozkou- mat pouze jejich spodní partie (doch. hloubka 3-22 cm, průměr do $40 \mathrm{~cm}$ ). Kůlové jámy tvořily pravidelný půdorys orientovaný ve směru východ - západ o rozměrech $10 \times 4$ metry. Byl dochován pouze v torzu, jeho východní část byla zničena hlubokou orbou a následnou skrývkou předcházející archeologický výzkum. Část by se mohla nacházet také mimo zkoumanou plochu. Objekty 38-44 se nacházely ve vnitřním vymezeném prostoru, mohou ukazovat na možné vnitřní uspořádání. Nález lze interpretovat jako pozůstatek po nadzemní kůlové stavbě, přičemž její datace vzhledem $\mathrm{k}$ absenci movitých nálezů není zcela jasná. Analogické obdélné domy kůlové konstrukce se objevují v prostředí únětické kultury (např. Březno u Loun: Pleinerová 2002; souhrnně Hásek 1954; Bláhová-Sklenářová 2012, 99-105 s řadou analogií pro d. bronzovou), v menším množství se s nimi setkáváme i v střední době bronzové (např. Olomouc-Slavonín: Bém 2005) a následně i mladší době bronzové (např. Gemeinlebarn, Rakousko: Neugebauer-Blesl 1998, Abb. 20:3), zde jsou však půdorysy staveb častěji méně obdélné a více se blíží čtvercovým (Bláhová-Sklenářová 2012, 105-116 s další literaturou). ${ }^{4}$

Jaká je souvislost kumulace kůlových jam 1446 s objektem 11 nacházejícím se bezprostředně v jihovýchodním sousedství není jasná, nelze s jistotou říci, zda se může jednat o dvě chronologicky totožné komponenty nebo zda je jejich stáří rozdílné. K objasnění tohoto problému by mohly napomoci metody z řad prŕrodovědných věd, bohužel ty nebyly vzhledem $\mathrm{k}$ charakteru záchranného výzkumu aplikovány.

\section{Závěr}

Skupina kůlových objektů, zkoumaných ve Velkém Přítočně, představovala zbytek kůlového stavení. V teoretické rovině lze uvažovat o jeho zařazení do doby bronzové. Druhou koncen- 
trací archeologických situací byl pozůstatek kruhového žlabu vyplněného velkými kameny, pravděpodobně pozůstatkem kamenného věnce. Plocha uvnitř věnce byla vyplněna terénní depresí s dvěma koncentracemi kamenů. Na základě nevýrazného keramického materiálu a kovovému artefaktu (snad šipce) nelze jednoznačně určit dataci objektu. Podle jeho typologie můžeme hovořit pravděpodobně o pozů- statku mohyly zařaditelné do doby bronzové. Vzájemnou souvislost kůlového domu a mohyly nelze prokázat. Další informace o lokalitě by mohl přinést až další archeologický výzkum na okolních plochách, dle sdělení místních obyvatel se na prrilehlém poli v minulosti nacházely nápadné koncentrace kamenů. Ty by mohly ukazovat na další rozorané kamenné konstrukce mohyl.

1) Objekty s číselným označením 1-9 byly při archeologickém výzkumu označeny jako pseudoobjekty, zbytky po vývratech apod., proto má první z popisovaných objektů č. 10.

2) Na zpracování archeologického výzkumu se podíleli studenti FF KAR ZČU v Plzni v rámci svých terénních praxí pod záštitou projektu SGS-2016-068 „Studium vybraných sídelních struktur dlouhého trvání v jižních a západních Čechách“.

3) Rozbor keramiky vychází z popisu z prací O. Chvojky (2009) a D. Hlásek a kol. (2015).

4) Za diskuzi nad tématem autoři děkují doc. Mgr. Ondřeji Chvojkovi, Ph.D., který připouští interpretaci kulové konstrukce jako nadzemní obytné stavby, nevylučuje však také její souvislost s pohřební komponentou.

\section{Literatura}

Beneš, A. 1959: K problémům mohylové kultury doby bronzové ve středních Čechách, Sborník Národního muzea 13, 1-93.

Beněs, A. - Michálek, J. - Zavřel, P. 1999: Archeologické nemovité památky okresu České Budějovice. Díl I. Soupis a studie. Díl II. Atlas, Praha.

Bém, M. 2005: Pravěké stavby na lokalitě Horní lán v Olomouci-Slavoníně. In: Archeologické centrum Olomouc, příspěvková organizace - Ročenka 2004: Olomouc, 126-172.

Bláhová-Sklenářová, Z. 2012: Obytné stavby doby bronzové - otázka stavebního a konstrukčního vývoje, Praehistorica 30/2, Praha.

Boháčová, I. 1992: Kyšice, okr. Kladno, Výzkumy v Čechách 1988 - 1989, 77.

Danielisová, A. - Langová, M. - Kočár, P. - Kyselý, R. Stránská, P. - Sĩvová, Z. - Světlik, I. 2013: Mohyla únětické kultury z Brandýsa nad Labem jako doklad ojedinělých pohřebních praktik starší doby bronzové, Archeologické rozhledy 65, 56-88.

Dreslerová, D. 2000: Hostouň, okr. Kladno, Výzkumy v Čechách 1998, 52-53.
Chvojka, O. 2009: Jižní Čechy v mladší a pozdní době bronzové. Dissertationes Archaeologicae Brunenses/Pragensesque 6, Brno.

Chvojka, O. - Michálek, J. - Zavřel, P. 2011: Výzkum mohyl z doby bronzové a halštatské u Radošovic, okres České Budějovice, Archeologické výzkumy v jižních Čechách 24, 41-77.

Hásek, I. 1954: Obydlí a sídliště v oblasti únětické kultury, Časopis Národního muzea, Řada A - historická 153, 1-27.

Hlásek, D. a kol. 2015: Vrcovice. Hradiště z počátku střední doby bronzové, Archeologické výzkumy v jižních Čechách - Supplementum 10, České Budějovice - Plzeň.

Hrala, J. 1973: Knovízská kultura ve středních Čechách. Archeologické studijní materiály 11. Praha.

Kostka, M. 2008: Omyl v Čakovicích aneb Další falešná svatyně, Archeologie ve středních Čechách 12 , 297-308.

Jančo, M. 2003: Tuchlovice, okr. Kladno, Výzkumy v Čechách 2000, 277.

Michálek, J. 1999: Mohylové pohřebiště ve Velké Dobré, okr. Kladno. Výzkum v letech 1890 až 1891, Archeologie ve středních Čechách 3, 113-153. 
Michálek, J. - Zavřel, P. 2010: Výzkum pravěké mohyly (kenotafu) u Lipí, okr. České Budějovice, Archeologické výzkumy v jižních Čechách 23, 125-142.

Moucha, V. 1985: Stehelčeves, okr. Kladno, Výzkumy v Čechách 1982 - 1983, 171-172.

Moucha, V. 1987: Lhota, okr. Kladno, Výzkumy v Čechách 1984-1985, 249.

Moucha, V, 1992: Velké Přítočno, okr. Kladno, Výzkumy v Čechách 1988-1989, 162.

Neugebauer, J. W. - Blesl, Ch. 1998: Das Traisental in Niederösterreich. Die Siedlungserschließung einer Tallandschaft im Alpenvorland in der Bronzezeit. In: Hänsel, B. (Hg.): Mensch und Umwelt in der Bronzezeit Europas. Kiel, 395-418.

Píc, J. L. 1892: Archeologický výzkum ve středních Čechách 5. Mohyly u Velké Dobré. Památky archeologické XV, 481-499, tab. XXII-XXIII.

Pič, J. L. 1900: Starožitnosti země české. Díl I, sv. 2. Pokolení kamenných mohyl, Praha.

Pleinerová, I. 2002: Dlouhé doby únětické kultury v severozápadních Čechách. In: Čech, P. - Smrž, Z. (eds.), Sborník Drahomíru Kouteckému, Most, $163-165$.

Plesl, E. 1965: Otázky středobronzového osídlení v severozápadních Čechách, Památky archeologické LVI, 457-512.

Procházka, M. 2012: Hostouň - knovízské sídliště „U hřiště“. In: Archeologické výzkumy v Čechách 2011: Sborník referátů z informačního kolokvia. Zprávy České archeologické společnosti - Supplément 85. Praha, 20.
Sklenář, K. 1992: Archeologické nálezy v Čechách do roku 1870. Praha.

Sklenár, K. 2000: K lokalizaci a datování mohyl u Blevic, okr. Kladno, Archeologie ve středních Čechách 4, 97-104.

Schmidt, V. 1893-1895: Archaeologický výzkum „Údolí Svatojiřského“ a okolí, Památky archeologické XVI, 1-30, 57-84, 113-140, 243-286, 361-386, 443-446, 593-636, 719-744.

Švejcar, O. - Baloun, L. - Trefný, M. 2012: Pohřební areál ze střední doby bronzové z Nymburska a problematika struktur tvořených kruhovými žlaby v Čechách, Archeologické rozhledy 64, 443-465.

Trefný, M. 2013: Objekty s kruhovými žlaby. Mohyly či ploché rovinné areály? Archeologie západních Čech 5, 125-135.

Trefný, M. - Doběs, M. 2008: Pohřebiště ze střední až mladší doby bronzové ve Straškově, okr. Litoměřice, Archeologie ve středních Čechách 12, 205-243.

Trefný, M. - Dobeš, M. 2010: K problému interpretace objektů s kruhovými žlaby na pohřebišti ze střední až mladší doby bronzové ve Straškově, okr. Litoměřice. In: Furmánek, V. - Miroššayová, E. (eds.), Popolnicová polia a doba halštatská, Zborník referátov z X. medzinárodnej konferencie „Popolnicová polia a doba halštatská, Nitra, 329-340.

Turek, J. - Sofaer, J. 2004: The excavation of a funerary area at Uhy (distr. Kladno). In: Gojda, M. (ed.), Ancient Landscape, Settlement Dynamics and Non-Destructive Archaeology, Praha, 286-305. 


\section{Ärchäologische Untersuchungen an einem Grabhügel und einem Pfahlhaus aus der Bronzezeit (?) in Velké Př́točno, Bezirk Kladno}

Im Jahr 2011 wurden im Katastergebiet der Gemeinde Velké Př́točno, Bezirk Kladno, archäologische Rettungsgrabungen durchgeführt. Auf einer Gesamtfläche von 1,5 ha wurden Funde in zwei Hauptkonzentrationen identifiziert. Die erste Konzentration besteht aus Pfahlgruben, welche wir aufgrund ihrer gegenseitigen räumlichen Beziehungen und anhand von Analogien als Überreste eines Pfahlhauses interpretieren (Obj. 14-46). Eine Datierung auf die Bronzezeit kann erwogen werden. Die zweite Konzentration ist der Überrest einer kreisförmigen, mit großen Steinen angefüllten Rinne mit einem Durchmesser von 10-12m. Eventuell handelt es sich um die Überreste eines Steinkranzes (Obj. 11). Die Steine liegen in vielen Fällen nicht an ihrem ursprünglichen Ort und sind, offensichtlich in Folge von Pflügearbeiten, leicht verschoben worden. Die Fläche innerhalb des Kranzes ist mit dunklerer Erde und zwei Steinhaufen ausgefüllt. Die Steine sind hier kleiner als diejenigen, die den Kranz bilden. An den Funden sind Beeinträchtigungen des Objekts aufgrund der geringen Mächtigkeit der Krume und der aktiven landwirtschaftlichen Nutzung offensichtlich. Die Funde können weder mit Sicherheit einem konkreten Ort zugeordnet noch können ihre gegenseitigen räumlichen Verhältnisse festgestellt werden. An Metallgegenständen wurden Bruchstücke von Bronzeteilen gefunden (wahrscheinlich Pfeile). Aufgrund des Typs des Objekts und der grundlegenden Eigenschaften des gefundenen Materials kann von Überresten eines Grabhügels ausgegangen werden, der möglicherweise der Hügelgräberkultur. Ein Zusammenhang zwischen dem Pfahlhaus und dem Grabhügel kann nicht belegt werden. Mit weiteren Beispielen aus jüngerer Zeit trägt dieser Fund zur Erforschung „verschwundener" mittelböhmischer Grabhügelfelder bei, welche durch Pflügearbeiten zerstört wurden. 
PhDr. Petr Menšík, Ph.D.

- Katedra archeologie, Filozofická fakulta Západočeské univerzity v Plzni

Sedláčkova 15, 30614 Plzeň

mensik.p@email.cz

\section{Mgr. Milan Procházka}

- Katedra archeologie, Filozofická fakulta

Západočeské univerzity v Plzni

Sedláčkova 15, 30614 Plzeň

milanprochi@seznam.cz 